\title{
Heart transplantation for adults with congenital heart disease: a single-center experience of 29
} years

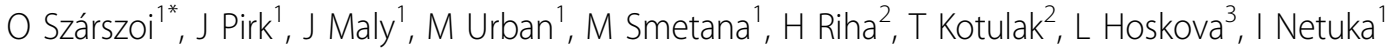 \\ From 23rd World Congress of the World Society of Cardio-Thoracic Surgeons \\ Split, Croatia. 12-15 September 2013
}

\section{Introduction}

Advances in palliation of congenital heart disease have resulted in improved survival to adulthood. Many of these patients develop end-stage heart failure requiring heart transplantation. In this study we analyzed the clinical profile and outcome of congenital heart disease patients transplanted at our institution.

\section{Methods}

Of 905 patients who underwent orthotopic heart transplantation at our institute from January 1984 to May 2013, 25 patients ranging in age from 18 to 54 years (18 male), in the end-stage of the heart failure were diagnosed to have congenital heart disease. We retrospectively reviewed the clinical data, operative and postoperative courses of these patients.

\section{Results}

Mean age was $36.2 \pm 10.9$ years. The main anatomical diagnoses were transposition of the great arteries, singleventricle defect, tetralogy of Fallot and Ebstein anomaly. Early, 1-, 5 and 10 -year survival was $88 \%, 88 \%, 73 \%, 60 \%$, respectively. Operative mortality for the study group was $8 \%$. There were 2 early deaths, both of which were related to early severe primary graft failure. Four patients from last three years were successfully bridged to heart transplantation with mechanical circulatory support.

\section{Conclusion}

Adult patients with congenital heart disease represent an increasing proportion of heart transplant recipients.

\footnotetext{
* Correspondence: onsz@ikem.cz

'Department of Cardiac Surgery, Institute for Clinical and Experimental Medicine, Prague, Czech Republic

Full list of author information is available at the end of the article
}

Despite high risk surgery because of their complex anatomy, prior surgical palliation, and hemodynamic status, with careful donor and recipient selection, these patients can have excellent early and mid-term survival after heart transplantation.

\section{Acknowledgements \\ Study was supported by Grant IGA MZ NT/11269 - 5 .}

\section{Authors' details}

'Department of Cardiac Surgery, Institute for Clinical and Experimental Medicine, Prague, Czech Republic. ${ }^{2}$ Department of Cardiac Anaesthesiology, Institute for Clinical and Experimental Medicine, Prague, Czech Republic. ${ }^{3}$ Department of Cardiology, Institute for Clinical and Experimental Medicine, Prague, Czech Republic.

Published: 11 September 2013

\section{doi:10.1186/1749-8090-8-S1-0150}

Cite this article as: Szárszoi et al:: Heart transplantation for adults with congenital heart disease: a single-center experience of 29 years. Journal of Cardiothoracic Surgery 2013 8(Suppl 1):0150.

Submit your next manuscript to BioMed Central and take full advantage of:

- Convenient online submission

- Thorough peer review

- No space constraints or color figure charges

- Immediate publication on acceptance

- Inclusion in PubMed, CAS, Scopus and Google Scholar

- Research which is freely available for redistribution

\section{Biomed Central}

C 2013 Szárszoi et al; licensee BioMed Central Ltd. This is an Open Access article distributed under the terms of the Creative Commons Attribution License (http://creativecommons.org/licenses/by/2.0), which permits unrestricted use, distribution, and reproduction in any medium, provided the original work is properly cited. 